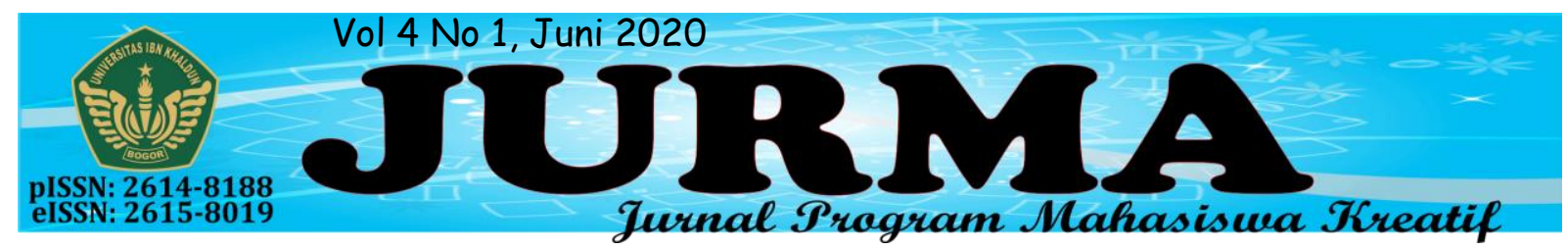

\title{
MEWUJUDKAN PROGRAM BANK SAMPAH SEBAGAI CARA MENINGKATKAN KREATIVITAS DAN EKONOMI WARGA KAVLING KRIDOSONO BLORA
}

\author{
Muttaqina Imama Wasanadiputra ${ }^{1}$, Atiqa Sabardila $^{2}$ \\ muttaqinaiw28@gmail.com \\ as193@ums.ac.id \\ Pendidikan Bahasa dan Sastra Indonesia, Universitas Muhammadiyah Surakarta
}

\begin{abstract}
ABSTRAK
Penelitian ini dilakukan untuk mengetahui bagaimana cara masyarakat Kavling Kridosono untuk mengurangi penumpukan sampah dengan cara mendaur ulang barang yang sudah tidak terpakai menjadi barang yang berguna kembali melalui program Bank Sampah ini. Penggunaan Bank Sampah ini merupakan cara alternatif untuk pengelolaan sampah,dengan program Bank Sampah ini masyarakat menjadi lebih peduli terhadap lingkungan sekitar sehingga lingkungan sekitar menjadi lebih sehat, element masyarakat dalam hal ini berperan sangat penting dalam program ini karena program ini menggunakan metode 3R ("Reduce, Reuse, Reycle”). Penelitian ini menggunakan metode deskriptif kualitatif yaitu mengumpulkan sampel data dari masyarakat di kawasan Kavling Kridosono biasanya masyarakat dengan rata-rata setiap kepala rumah tangga mampu menyetorkan sampah kurang lebih 1 kilogram sehari, sampah yang disetorkan berupa plastik bekas detergen dan kaleng bekas wadah biskuit, botol bekas air mineral dan lain lain setelah barang terkumpul semua barulah esok harinya warga yang berpartisipasi untuk memproduksi barang yang sudah dikumpulkan dan dijadikan kerajinan tangan . Data diperoleh dengan cara observasi ke tempat program Bank Sampah sehingga peneliti dapat memahami fenomena apa yang dialami oleh subjek penelitian secara deskriptif dalam bentuk kata-kata dan bahasa. Temuan yang didapat dalam penelitian ini adalah pembaca dan penulis menjadi tahu cara yang digunakan untuk mendaur ulang sampah kemudian menjualnya guna menambah pendapatan masyarakat sekitar dan mampu menjadikan lingkungan sekitar Kavling Kridosono bebas limbah dan lebih meningkat kualitas kesehatannya.
\end{abstract}

Kata Kunci : sampah, daur ulang, kebersihan

\section{PENDAHULUAN}

\section{Latar Belakang}

Pada era globalisasi yang terjadi zaman ini, tentunya kita sebagai masyarakat harus mempunyai inisiatif cara dan kretaifitas. sampah merupakan barang yang tidak dipergunakan kembali,
Banyak sampah-sampah dan barang yang tidak terpakai berserakan dimanamana dan menjadi limbah dipemukiman warga. Hal ini mendorong warga Kridosono untuk berfikir bagaimana cara sampaha atau barang tidak terpakai ini bisa menjadi barang yang bisa dimanfaatkan. 
Hal ini memicu kesadaran masyarakat membuat bank sampah ini sebagai tujuan alternatif untuk menyelesaikan seluruh pokok masalah penimbunan sampah menggunakan Teknik daur ulang barang tidak terpakai dilingkungan masyarat sehingga dapat mengurangi limbah yang tidak terpakai.

Tidak semua sampah bisa digunakan hanya yang masih layak dan bagus yang bisa digunakan seperti bungkus detergen,botol bekas air mineral,bekas wadah kaleng tak hanya itu sampah dari alam pun juga bisa digunakan sebagai pupuk kompos dan plastik bisa gunakan sebagai tas,bekas wadah cat bisa menjadi pot bunga. Pemanfaatan limbah yang seperti ini tentunya kita bisa lebih menyayangi bumi kita dan membatu merawat alam disekitar kita tentunya.

\section{Rumusan Masalah}

Bagaimana cara masyarakat Kavling Kridosono dalam menangani bank sampah yang ada di lingkungan mereka sehingga dapat meningkatkan kreativitas dan ekonomi lalu Bagaimana kondisi bank sampah di Kavling Kridosono sebelum dan sesudah adanya program.

\section{TINJAUAN PUSTAKA}

Sampah biasanya dibagi menjadi dua jenis yaitu sampah organik dan sampah anorganik. Bank sampah pada dasarnya adalah program daur ulang. Bank sampah merupakan metode yang menerapkan cara 3R (Reuse, Reduce, Recycle) dalam mengelola sampah pada titik permasalahannya. Berkontribusi dalam mengikuti program bank sampah berarti telah membantu proses perilaku daur ulang.

Pemanfaatan soal sampah yang sering menjadi pokok masalah untuk warga sekitar dan pihak berwajib perlu ditindak lanjuti supaya masalah tersebut

\section{Tujuan Penelitian}

Untuk menganalisis bagaimana cara masyarakat Kavling Kridosono dalam menangani bank sampah yang ada di lingkungan mereka sehingga dapat meningkatkan kreativitas dan ekonomi dan untuk menganalisis kondisi bank sampah di Kavling Kridosono sebelum dan sesudah adanya program

\section{Manfaat Penelitian}

Secara teoritis, penelitian ini bermanfat untuk mengajak masyarakat agar lebih mengerti tentang kebersihan lingkungan dan pentingnya mengurangi limbah dilingkungan sekitar dengan cara mendaur ulang. Manfaat bagi penulis yaitu menambah wawasan ilmu dan pengetahuan. Sementara bagi pembaca, penelitian ini bermanfaat untuk meningkatkan wawasanya dalam mengolah limbah atau barang yang tidak terpakai menjadi barang yang bermanfaat sehingga bisa menjadi bahan yang dapat digunakan kembali dan menambah penghasilan melalui penjualannya.

bias terselesaikan dan dikendalikan dalam undang-undang nomor 18 Tahun 2008 tentang pengelolaan sampah masyarakat hendaklah ikut serta membantu mengelola sampah dengan cara memilah mana sampah organic dan mana sampah anorganik. Masyarakat memandang bahwa sampah hanya barang yang digunakan beberapa kali saja selebihnya tidak berguna lagi. Sampah yang sekali digunakan biasanya langsung dibuang oleh pemiliknya padahal jika diolah bias mempunyai nilai jual, oleh karena itu beberapa kalangan masyarakat yang peduli 
lingkungan sekitarnya berinisiatif membangun komunitas Bank Sampah untuk menjadikan sampah tersebut menjadi barang yang bisa berguna kembali dan juga punya nilai jual.

Bank sampah adalah bentuk naungan bagi warga untuk menyetorkan sampah yang sebelumnya mereka sudah membedakan jenisnya kemudian baru diolah supaya mempunyai harga jual

\section{METODE PENELITIAN}

Penelitian ini dilaksanakan di Kavling Kridosono RT03 RW 05 Kecamatan Blora, Kabupaten Blora. Jenis penelitian ini adalah kuantitatif deskriptif. Pada program di Kavling Kridosono ini meminta warga sekitar untuk ikut serta dalam mengelola program bank sampah untuk menyetorkan barang yang sudah tak terpakai untuk dibuat karya yang mempunyai nilai jual. Penelitian ini juga

\section{HASIL DAN PEMBAHASAN}

Tujuan Pertama : Untuk menganalisis bagaimana cara masyarakat Kavling Kridosono dalam menangani bank sampah yang ada di lingkungan mereka sehingga dapat meningkatkan kreativitas dan ekonomi

Penanaman cinta lingkungan sebagai cara mengurangi sampah merupakan cara untuk mendaur ulang barang tak terpakai menjadi berguna dan bisa menghasilkan rupiah.Hal ini ditunjukkan oleh perilaku masyarakat di Kavlingan Krdisono RT 03 RW 05 Kecamatan Blora Kabupaten Blora.Keberadaan Bank Sampah Kaplingan Kridosono ini memberikan manfaat langsung yaitu lingkungan terbebas dari sampah ,membentuk ekonomi warga menjadi mandiri, mendorong warga menjadi kreatif dan berinovasi supaya masyarakat menjadi ekonomis. Partisipasi masyarakat menjadi salah satu faktor dalam menyukseskan program lingkungan, seperti bank sampah. Sikap wajib masyarakat untuk berpartisipasi menjadi kebalikan dari arah bahwa lingkungan hidup adalah milik bersama yang pemeliharaannya harus dilaksanakan oleh pihak yang berwajib, pelaku usaha, dan masyarakat.

mengajak masyarakat untuk lebih menyayangi lingkungan sekitar supaya bebas dari timbunan sampah dan juga terlihat indah . Data yang diperoleh dalam penelitian ini berupa kegiatan yang dilakukan masyarakat untuk memantau sejauh mana masyarakat mampu mendaur ulang sampah untuk dijadikan benda yang mempunyai nilai jual.

lebih sejahtera,dengan memakai sistim ini masyarakat selain mempunyai sikap yang mandiri untuk memilah sampah dan barang yang tak terpakai juga memperoleh pendapatan lebih dari sampah dan barang tak terpakai yang dikumpulkan warga.

$$
\text { Cara masyarakat Kridosono }
$$

meningkatkan kreatifitas yakni dengan mengolah dan dijadikan beraneka ragam barang yang bermanfaat dan berguna tetapi tak semua sampah bisa didaur ulang. Sampah dipilih yang sekiranya masih bagus dan masih layak. Sebelum diproses untuk diolah kembali sampah harus melalui proses pemilahan sesuai jenis sampah baik sampah golongan organik maupun golongan anorganik

Sampah biasanya terbagi berdasarkan lokasi dan didefinisikan menjadi dua bagian, yang pertama yaitu 
sampah yang berasal dari kota besar biasa disebut urban, sampah ini biasanya menumpuk dipusat kota besar, yang kedua yaitu sampah daerah, sampah ini biasanya mengelumpuk dan terkumpul di area-area luar pusat kota contohnya di kampung,permukiman gunung,dan pantai . Cara yang digunakan masyarakat Kridosono yaitu pengolahan sampah dengan mendahulukan cara pengendalian diri sendiri untuk meminimalisir membeli produk barang yang menyebabkan munculnya sampah(reduce), memakai lagi barang yang masih mampu digunakan (reuse) dan mengolah kembali sampah untuk dijadikan barang yang mempunyai nilai jual (rycle) yang biasanya disebut dengan metode 3R, berdasarkan masyarakat tentu dapat menjadikan imajinasi sebagian warga terhadap sampah yang sudah tidak mempunyai nilai jual ekonomis. Berikut cara masyarakat Kavling Kridosono mengolah sampah organik, sebelumnya sampah organik adalah sampah yang cepat sekali membusuk. Terdapat salah satu upaya/pemecahan masalah barang tak terpakai lainnya adalah dengan cara mendaur ulang sampah kemudian dilanjutkan dengan cara memisahkan bagian-bagian sampah yang sudah terbagi menjadi 3 bagian yang pertama yaitu Sampah basah: sampah yang mengandung banyak air dan sangat gampang mengurai sendiri cepat membusuk, antara lain bekas makanan yang tidak habis, sayuran, aneka buah, sampah yang berasal dari sisa kebun dan sampah rumah tangga. Yang kedua yaitu sampah kering: sampah yang kandungan airnya kecil tidak dapat membusuk kemudian terurai sendiri secara alami, antara lain kertas, kayu, ranting pohon, plastik, tekstil, dedaunan kering, toples bekas kue, kaleng bekas cat, dan masih banyak lainnya, yang ketiga yaitu Sampah B3 yang berarti "bahan yang berbahaya dan beracun" sampah ini cenderung sangat berbahaya untuk kesehatan dan kelangsungan hidup organisme lainnya,berikut contoh sampah B3 : batrai bekas,sisa cat,pestisida,limbah bekas rumah sakit, dan lain-lain.

Memisahkan sampah sangatlah mudah dan gampang tergantung pada keinginan diri sendiri maka dari itu kita harus membiasakan diri setiap hari untuk membuang sampah pada tempat yang sudah disediakan, biasanya tersedia 3 tempat sampah yang terdiri dari pertama (1) : tempat sampah kering, kedua (2) tempat sampah basah, ketiga (3) tempat sampah 3B. Dimasa lalu dan masa sekarang mungkin rata-rata masih bertahan bahwa sampah yang dibuang dan dibakar begitu saja dapat mengakibatkan polusi udara dan residu yang menyebabkan lingkungan sekitar menjadi membahayakan, sampah basah yang bisa didaur ulang kembali dan dijadikan pupuk kompos dengan cara pengolahan tertentu sesuai prosedur yang akhirnya mampu dimanfaatkan sebagai pupuk organik untuk tanaman dan mampu meningkatkan hasil produk tanaman yang mampu membuat konsumen menjadi puas dan nilai jual semakin tinggi tentunya juga lebih menyehatkan bagi tanaman.mengolah ulang sampah organik bekas sisa rumah tangga dengan metode pengomposan secara tidak langsung melangsungkan kaidah cara mendaur ulang dalam rangka menghijaukan lingkungan sekitar. Prosesnya tidaklah sulit hanya mengandalkan sedikit niat usaha diri dan waktu, seterusnya kita serahkan pada alam untuk melanjutkan pengolahan karena alam mampu membuat bahan organik terurai secara alami dan menjadi pupuk 
kompos. Manfaat kompos yang lebih rinci antara lain : pertama yaitu aspek ekonomi mampu menggunakan biaya untuk lebih hemat untuk transportasi dan penumpukan sampah, karena dilakukan setempat menurunkan volume atau ukuran sampah mempunyai nilai jual yang lebih besar dan menguntungkan dari pada bahan aslinya. Yang kedua aspek lingkungan : dapat menurunkan polusi udara yang disebabkan oleh limbah yang dibakar dan gas metana yang keluar bebas diudara, sampah organic yang membusuk yang disebabkan oleh bakteri metanogen ditempat pembuangan sampah : menurunkan keperluan lapangan untuk penumpukan, yang ketiga aspek untuk lahan/tanaman: mengoptimalkan kesuburan tanah menjadi lebih tinggi,tanah; menjadikan struktur lebih baik dan karakteristik tanah; menaikkan mutu dan kualitas hasil panen terhadap rasanya, nilai gizi dan keseluruhan total panen. Manfaat sampah kering lainnya berupa : pertama langsung bisa diperjual belikan ke pelapak dengan harga jual sesuai dengan kualitas dan mutu sampah keringnya, yang kedua Bisa digunakan kembali sebagai pot bunga, peralatan, wadah penyimpanan barangbarang, dan masih banyak lain,yang ketiga bisa dapat diolah menjadi olahan tangan warga yang ekonomis dan mempunyai nilai jual ekonomis tinggi. Padahal sampah kering yang sudah tidak dapat diolah kembali (residu) lalu dibuang ke pembuangan akhir (TPA) dan bank sampah merupakan metode cara untuk mengolah sampah kering tersebut.

Hasil dari nasabah menabung dan hasil dari terjualnya produk tersebut mampu meningkatkan pendapatan ekonomi nasabah untuk membantu memenuhi keperluan sehari-hari. Hal ini menunjukan bahwa masyarakat sudah mengetahui dan paham akan pengelolaan sampah yang tepat. Masyarakat memiliki persepsi/ cara pandang yang baik terhadap sampah. Masyarakat sudah memahami bahwa tidak semua sampah yang mereka hasilkan merupakan barang yang "tidak bernilai" dan "kotor" akan tetapi ada sebagian yang memiliki "nilai" dan masih bisa dimanfaatkan bahkan bernilai ekonomi.Hal utama yang menyebabkan ekonomi merupakan hal utama dalam meningkatkan kesuksesan pada terlaksananya program bank sampah ini.

Dengan harapan didirikannya Bank Sampah ini bisa ikut menolong dan bisa ikut mengatasi mengatasi persoalan sampah serta mampu memaksimalkan pendapatan keluarga yang menjadi nasabah di bank sampah terutama Kavling Kridosono, dengan langkah bank sampah ini akhirnya mampu menemukan salah satu pemecah masalah yang inovatif dan akan mempunyai nilai ekonomi jika sampah yang ada mencukupi syarat yang untuk diperjual belikan atau didaur ulang kembali secara lebih tepat dan dijadikan barang yang ekonomis salah satunya sebagai bahan dasar daur ulang maupun barang utama untuk diperjual belikan. Jika masyarakat yang sebagai pengimpor sampah aktif ikut serta dalam proses pengolahan sampah contohnya $3 \mathrm{R}$, maka mengumpulkan dan memperjual belikan sampah tersebut harus mempunyai wadah. Mulai dari sinilah mampu melihat melihat tujuan utama bank sampah sebagai perantara masyarakat untuk menyisihkan uang dan membantu meningkatkan nilai social ekonomi warga dan serentak memberdayakan warga dalam proses daur ulang sampah. Bank Sampah merupakan wadah untuk menabung sampah sesuai sampah yang sudah dibedakan jenisnya

Bank sampah memiliki cara bekerja yang sama pada umumnya, yaitu bank 
sampah juga mempunyai nasabah,catatan tabungan, dan pengelolaan manajemen. Apabila pada umumnya nasabah menyetorkan sejumlah uang ini sebaliknya pada bank sampah yang disetorkan adalah sejumlah barang yang tak terpakai yang masih bagus dan bernilai ekonomis. Dalam pengelolaan bank sampah harusnya dikelola oleh masyarakat yang mempunyai jiwa kreatif dan inovatif yang disertai jiwa wirausahawan supaya bisa menambah pendapatan masyarakat. Cara kerja bank sampah dilaksanakan berdasarkan rumah tangga dengan cara memberi hadiah pada masyarakat yang dapat membedakan sampah sesuai jenisnya dan mengumpulkan sejumlah sampah yang sudah ditentukan. Rancangan bank sampah mengambil konsep manajemen bank pada dasarnya.Selain dapat digunakan sebagai perantara untuk seruan menghijaukan lingkungan, daur ulang sampah juga dapat dijadikan ajakan masyarakat dan anakanak menjadi gemar menabung dan cinta lingkungannya .

Bank sampah juga berfungsi antara lain mampu meningkatkan pendapatan masyarakat yang disebabkan ketika penukaran sampah mereka mendapatkan uang. Masyarakat juga mampu menarik uang yang terdapat pada bank sampah sewaktu-waktu ketika dibutuhkan dengan syarat tabungan sampahnya sudah terkumpul sesuai aturan. Upah yang dibagi kepada nasabah bukan hanya sekedar uang tetapi juga ada yang berjenis bahan pokok sembako berupa kopi,beras,mie instant,shampoo,pulsa listrik, sabun cuci,teh dan masih banyak lainnya

Tujuan 2 : Untuk menganalisis kondisi bank sampah di Kavling Kridosono sebelum dan sesudah adanya program.
Permasalahan yang ada di lingkungan sekitar kita sering sekali terjadi pada sampah yang menimbun. Sampah tersebut kebanyakan berasal dari sampah rumah tangga. Hampir pada setiap rumah warga pasti menghasilkan suatu sampah, baik sampah organik yang berasal dari tumbuhan dan sisa makanan maupun sampah anorganik yang berasal dari palstik, besi, aluminum dll. Sampah yang demikian sangat berpengaruh pada pencemaran lingkungan dan mengakibatkan rusaknya lingkungan yang sehat. Namun jika proses cara mendaur-ulang barang tak terpakai secara buruk juga akan menimbulkan keresahan pada masyarakat itu senidiri. Sejumlah masyarakat bisa juga dengan mudah tertular penyakit yang disebabkan lingkungan di tempat tinggalnya tidak sehat .

Sebagai masyarakat kita seharusnya sadar akan kebersihan lingkungan sekitar kita agar lingkungan sekitar kita terlihat bersih, rapi, dan indah dipandang. Selain bersih, rapi, dan indah dipandang lingkungan yang bersih juga akan membuat hidup kita menjadi lebih bersih dan sehat. Kita juga akan terhindar dari segalam macam penyakit.

Sebelum adanya program Bank Sampah di tengah-tengah masyarakat Kavling Kridosno, lingkungan Kavlingan Kridosono terlihat sangat kurang bersih, banyak tumpukan sampah yang menimbun. Rendah kesadaran masyarakat tentang kebersihan lingkungan juga terlihat ketika banyak sampah-sampah yang tergletak dimana-mana, terjadi banyak penimbunan sampah dan barang yang tidak terpakai dirumah masyarakat. Hal tersebut tentu akan berdampak timbulnya bencana banjir dan berbagai macam penyakit.

Sampah juga merupakan salah satu faktor penyebab rusaknya alam di sekitar, 
ketika sampah menganggu dan dianggap menjadi hal yang negatif bagi masyarakat sebab sampah-sampah biasanya menimbun di lahan kosong milik sejumlah masyarakat. Ketika menimbunnya sampah tersebut dibiarkan begitu saja, akan menimbulkan pencemaran tanah dan kondisi lingkungan. Secara langsung maupun secara tidak langsung juga akan mempunyai pengaruh yang kuat pada kesehatan masyarkat Kavling Kridosono itu sendiri.

Sampah yang semakin banyak tertimbun di lingkungan Kavlingan Kridosono juga akan mengakibatkan munculnya masalah yang besar, sehingga membutuhkan penanganan yang bisa menjadikan sampah sebagai barang yang bisa digunakan kembali. Mau tidak mau sebagian besar masyarakat harus memutar otaknya untuk mencari jalan keluar untuk mengatasi masalah penimbunan sampah yang marak terjadi di lingkungan sekitar ini. Karena apabila hanya dengan mengandalkan tenaga dari petugas sampah yang hanya beberapa kali dalam seminggu menghampiri pada tiap-tiap rumah untuk mengambil sampah, hal itu sangat kurang efektif dalam memaksimalkan tujuan lingkungan yang bersih.

Ketika masyarakat telah menemukan cara guna memberantas penimbunan sampah dan barang yang tidak terpakai lingkungan sekitar masyarakat akan menjadi bersih dan indah. Apabila keadaan di lingkungan sekitar bersih dari sampah, itu artinya masyarakat akan terbebas dari segala macam penyakit yang diakibatkan kotornya lingkungan. Penyakit yang mungkin muncul apabila lingkungan yang tidak bersih antara lain gatal gatal pada kulit hingga iritasi dan infeksi kulit, demam berdarah karena nyamuk Aides Aigepty, dan lain sebagainya.
Hingga pada suatu saat pada sekitar tahun 2014, kesadaran masyarakat akan pentingnya menjaga lingkungan di Kavlingan Kridosono sedikit demi sedikit mulai muncul. Hal itu bermula ketika ada ajakan dari salah satu warga perumahan yang mendapatkan informasi mengenai bank sampah dari social media. Mulai dari ajakan salah satu masyarakat tersebut itulah masyarakat yang lain juga mulai tumbuh kesadarannya untuk mengelola barang yang sudah tidak dipakai agar tidak menjadi sampah yang tidak berguna dan tidak memiliki harga jual tinggi. Hal pertama yang dilaksanakan oleh kebanyakan masyarakatnya yaitu dengan rencana pembuatan suatu program kebersihan lingkungan. Mereka bergotong royong membuat program bank sampah di lingkungan Kavling Kridosono ini. Bertempat di Jalan Camar, program bank sampah tersebut mulai didirikan. Lambat laut tidak sedikit warga yang ikut membantu proses pembangunan tersebut mulai dari remaja sekitar, karangtaruna, orang tua, ibu ibu PKK semua juga ikut serta berpartisipasi.

Semenjak ada program alternatif bank sampah yang berdiri di wilayah Kavlingan Kridosono, kini banyak masyarakat yang mengumpulkan sampah atau barang yang tidak terpakai milik mereka untuk disetor pada bank sampah agar dapat didaur ulang di sana. Biasanya masyarakat sekitar akan membawa toples bekas, plastik bekas, kaleng bekas, bahkan ada juga yang membawa daun daun yang kering. Daun yang kering itu biasanya dimasukkan kedalam tong lalu didiamkan beberapa hari dan hingga dapat dijadikan pupuk kompos untuk keperluan pribadi misalnya pupuk tanaman hias maupun menjadi campuran untuk pupuk tanaman mereka yang ada di kebun miliknya. Pupuk 
ini juga dapat diperjual belikan, sehingga ada banyak juga warga yang biasanya menjual pupuk kompos tersebut. Selain daun kering yang dijadikan pupuk kompos, olahan daur ulang yang berupa kaleng bekas biasanya juga dijadikan sebagai pot bunga, plastik biasanya diolah menjadi tas. Barang barang bekas yang lain juga ada yang dijadikan gantungan kunci dan banyak lagi kerajinan yang lainnya. Pendirian bank sampah ini sangat menjadi momentum kebaikan dan kemajuan bagi masyarakat Kavlingan Kridosono dalam membina kesadaran masyarakat dalam membedakan jenis, mengolah kembali dan memanfaatkan barang lama tak terpakai untuk menjadikan barang bekas mempunyai harga dagang yang ekonomis sehingga dampaknya pun dapat dikatakan sangat berhasil dalam mengubah lingkungan yang berada di sekitar perumahan masyarakat Kavling Kridosono. Tidak ada lagi tumpukan sampah yang menimbun dan secara tidak langsung dengan adanya program bank sampah yang sedang berlangsung tersebut sangat membantu pekerjaan para petugas sampah yang biasanya membersihkan dan sekaligus mengangkut sampah di lingkungan Kavling kridosono ini. Adanya kegiatan bank sampah ini membantu kita sebagai warga perumahan dalam memperbaiki keseimbangan alam.

Bank sampah juga mampu dijadikan penyelesaian alternatif yang menjadikan lingkungan masyarakat yang resik, indah,sehat bagi masyarakat. Dengan cara kerja ini dan alternatif bank sampah masyarakat menjadi tahu dan mandiri dalam mengolah barang lama, merekapun juga akan mendapat tambahan rejeki dari sampah dan barang lama yang mereka kumpulkan. Dengan cara bank sampah inilah merupakan cara alternatif yang dapat menyelesaikan pokok masalah tentang sampah dan juga cara berpartisipasi merawat lingkungan sekitar dan juga berdampak pada planet bumi yang kita tinggali ini, secara tidak langsung pasti juga akan berdampak Panjang bagi kehidupan manusia yang dihidup dibumi ini.

Masalah sampah tidaklah masalah yang mudah dan dilantarkan begitu saja, dalam permaslahan ini dibutuhkan kesadaran diri sendiri dan tindakan yang nyata, gotong royong antar warga dan masalah sampah pasti akan terselesaikan menggunakan metode bank sampah. Pengelolaan sampah dan barang tidak terpakai yang efektif di bank sampah menjadikan kita sebagai masyarakat mampu mengetahui keefektifan sampah. Tidak akan ada lagi kemungkinan sampah yang tercecer begitu saja. Setiap jenis sampah akan ditaruh sesuai jenis sampah tersebut . Sampah organik akan diubah dan dijadikan pupuk kompos sedangkan sampah anorganik dibersihkan kemudian disetor untuk didaur ulang kembali. Aktivitas pengolahan sampah yang efektif dan positif ini akan menjadikan lingkungan bersih,aman dan nyaman untuk menetap , pengolahan sampah adalah dasar pokok bagi terciptanya lingkungan yang bersih, aman, dan nyaman, selain itu juga wujud sebagai kepedulian dan tanggung jawab kita sebagai masyarakat. 


\section{KESIMPULAN}

Berdasarkan penelitian yang telah dilakukan sesuai hasil analisis data dan pembahasan yang telah diuraikan dapat diambil 2 kesimpulan sebagai berikut

1. Kegiatan pelaksanaan program Bank Sampah di Kavling Kridosono ini sudah terlaksana sejak tahun 2014 yang terbentuk karena salah seorang warga yang melihat di berita lalu mengajak sesama warga untuk meningkatkan keperdulian warganya yang rendah terhadap kebersihan lingkungan sekitar pemukiman, pelaksanaan program bank sampah tersebut sangat mendukung adanya peningkatan kebersihan lingkungan dan meningkatkan kreatifitas warga Kavling Kridosono

\section{DAFTAR PUSTAKA}

Astuti Farida Afriani, Dina Asrifah, Ika Wahyuning Widiarto, Ayu Utami, dan Dian Hudawan Santoso. 2018. "Identifikasi Presepsi Pola Perlakuan Sampah Oleh Masyarakat Dalam Meningkatkan Efektivitas Pengelolaan Sampah diKota Yogyakarta". Jurnal Science Tech, 4 (2): 59-66.

http://jurnal.ustjogja.ac.id/index.php/ sciencetech/article/view/2678

Azrai Eka Putri, Ernawati, dan Santi Rizkiani. 2016. "Hubungan Presepsi Ibu Rumah Tangga Tentang Bank Sampah dengan Partisipasi Pengelolaan Bank Sampah Gawe Rukun,Kota Tangerang". Jurnal Pendidikan Biologi (Biosferjpb), 9 (2): 60-68. http://journal.unj.ac.id/unj/index.php/ biosfer/article/view/5570/4158 dengan cara mengolah sampah yang sudah disetorkan pada program Bank Sampah tersebut

2. Sebelum adanya program Bank Sampah lingkungan di Kavling Kridosono cenderung agak kurang tertata karena ada penimbunan di tong sampah dan sesudah dijalankannya program Bank sampah sedikit mengubah keadaan di lingkungan menjadi lebih bersih karena warga mampu mengolah sampah menjadi barang yang mempunyai nilai jual. Dengan juga adanya Bank Sampah ini juga bisa membantu pendapatan ekonom dengan cara menjual karya hasil olahan masyarakat yang ikut berpartisipasi

Fauzi Mohammad Ridho, Suwarno, dan Sutomo. 2017. "Partisipasi Masyarakat Dalam Program Bank Sampah "Pendowo Berseri" Desa Tretih Wetan Kecamatan Jeruklegi Kabupaten Cilacap". Geo Edukasi, 6 (2): 43-48. http://jurnalnasional.ump.ac.id/index. php/GeoEdukasi/index

Fitria Laili dan Ulili Kadaria. 2018. "Analisis Bibliometrik dari Penelitian Bank Sampah untuk Pengelolahan Persampahan".Jurnal Teknologi Lingkungan Lahan Basah, 6 040-052. http://jurnal.untan.ac.id/index.php/jm tluntan/article/view/37076

Fitri Rizka Firdausa, Nurul Umi, dan Suyeno. 2019. "Implementasi Kebijakan Pemerintah Dalam Inovasi Pengelolaan Sampah Terpadu (Studi 
Kasus di Taman Tempat Pembuangan Akhir (TPA) Randegan Kota Mojokerto)". Jurnal Respon Publik, $13 \quad$ (4) : 12-18. http://riset.unisma.ac.id/index.php/rp p/article/view/3577

Hasnam Linda Fitria, Rizal Syarif, dan Akhmad Muklis Yusuf.2017. "Strategi Pengembang Bank Sampah Di Wilayah Depok". Jurnal Aplikasi Bisnis Manajemen, 3 (3) : 407-416. https://journal.ipb.ac.id/index.php/ja bm/article/view/13637

Jastaim Muhammad Saleh. 2015. "Pemberdayaan Masyarakat Melalui Pengelolaan Sampah (Studi Kampus di Bank Pelita Harapan,Kelurahan Ballaparang,Kecamatan

Rappocini,Makassar)". Higinie, 1 (1) : 43-48. http://journal.uinalauddin.ac.id/index.php/higiene/arti cle/view/1217

Kusuma Dhita Prima dan Yuli Astuti. 2017. "Sistem Pengelolaan Data Bank Sampah (Study Kasus: Bank Sampah Bangkit Pondok 1 Ngemplak Sleman)". Jurnal Manajemen Informatika, 21 (1) : 32-41. http://ejurnal.pelitanusantara.ac.id/index.ph p/mantik/article/view/187

Komalasari Yeyen,Eka Putri Suryantari,Ni Ketut Martini. 2019. "Pendekatan Komprehensif Bank Sampah sebagai Alternatif Pengelolaan Sampah". Jurnal Paradharma, 3 (2) : 120-128. https://jurnal.undhirabali.ac.id/index. php/para_dharma/article/view/1047

Munawir. 2015. "Upaya Pemberdayaan Masyarakat dan Penanganan Lingkungan".Buletin Dan Bisnis
Manajemen,01(01):31-37

https://journal.stie-

yppi.ac.id/index.php/BBM/article/do wnload/111/101

Prastyo Danang, Aditya Bagus Pramono, dan Tede Iren Rahayaan. 2017. "Pelaksanaan Program Bank Sampah Dalam Sistim Pengelolaan Sampah di Desa Jogodalu Kecamatan Benjeng Kabupaten Gresik". Penamas Adi Buana, 1 (1) : 7-12. http://jurnal.unipasby.ac.id/index.php /penamas/article/view/683

Pratama Reba Anindyati dan Iif Miftakhul Ihsan. 2017. "Peluang Penguatan Bank Sampah untuk Mengurangi Timbulan Sampah Perkotaan (Studi Kasus Bank Sampah Malang)". Jurnal Teknologi Lingkungan, 18 (1) 112-119. http://ejurnal.bppt.go.id/index.php/JT L/article/view/1743

Prayati Ni Made Via dan Kartika I Nengah.2018."Analisis Pengaruh Program Bank Sampah Terhadap Pendapatan Nasabah Bank di Kota Denpasar".E Jurnal Ekonomi Pembangunan Universitas Udayana, 7(6):1256:1281.

https://ojs.unud.ac.id/index.php/eep/a rticle/view/38930.

Samudro Ganjar, Budi Prastyo Samadikum, dan Fipin Dwi Solekhah. 2019. "Edukasi Bank Sampah Dalam Rangka Meningkatkan Kinerja Sistem Pengelolahan Persampahan Kawasan Perumahan Permata Tembalang Kelurahan Kramas Kota Semarang".JurnalPasoepati,1(3):116 $-121$. 
https://ejournal2.undip.ac.id/index.ph p/pasopati/article/view/5492

Selomo Makmur, Agus Bintara Birawida, Anwar Walongi, dan Muammar. 2016. "Bank Sampah Sebagai salah Satu Fungsi Penanganan Sampah di Kota Makassar".Jurnal Mkmi,12(4):232-240.

http://journal.unhas.ac.id/index.php/ $\underline{\mathrm{mkmi} / \text { article/view/1543 }}$

Suryani Anih Sri.2014."Peran Bank Sampah Dalam Aktivitas Pengelolaan Sampah (Studi Kasus Bank Sampah Malang".Aspirasi,5(1):71-84. https://jurnal.dpr.go.id/index.php/asp irasi/article/view/447/344

Tanuwijaya Fransiska. 2016. "Partisipasi Masyarakat dalam Pengelolaan Sampah di Bank Sampah Pitoe Jimbangan Kota Surabaya". Kebijakan Dan Manajemen Publik, 4 (2) 230-244. http://repository.unair.ac.id/41351/
Triana Anisa Putri dan Emenda Sembiring. 2018. "Evaluasi Kerja dan Kelanjutan Program Bank Sampah Sebagai Salah Satu Pendekatan Dalam Pengelolaan Sampah dengan Konsep 3R (Studi Kasus di Kota Cimahi)". Jurnal Teknik Lingkungan, 24 69-78. http://journals.itb.ac.id/index.php/jtl/ article/view/13271/0

Umyati Ani, Yanyan Dwiyanti, dan Tri Partuti. 2018. "Pengaruh Program Bank Sampah Terhadap Tingkat Pendapatan Keluarga Nasabah Bank Sampah Mandiri di Kelurahan Kebonsari". Jurnal Industrial Service, $4 \quad$ (1) : 64-68. http://jurnal.untirta.ac.id/index.php/ji ss/article/view/4090

Yusfi Rosi Nuraeni dan Tri Padmi Damanhuri. 2012. "Studi Karakteristik dan Potensi Daur Ulang Sampah di Bantaran Sungai Cikapundung". Jurnal Teknik Lingkungan, 18 (2) : 155-166. http://journals.itb.ac.id/index.php/jtl/ article/view/8285 